\title{
Gravidez na adolescência, questão feminina? Uma reflexão sobre o papel paterno
}

\author{
Duarte, Josmar B. ${ }^{1}$ Duarte, Ana C. S. ${ }^{2}$
}

Recibido: 22/09/2016

Aprobado: 10/11/2016

\section{Resumo}

A gravidez, a maternidade e a paternidade não planejada entre adolescentes são assuntos que vêm preocupando, nas últimas décadas, especialistas e governantes das áreas dos direitos humanos, bem como pesquisadores e acadêmicos. Este estudo pretendeu colaborar para a sistematização do conhecimento científico e acadêmico sobre a paternidade adolescente e o exercício da função paterna. Temática que ainda é pouco explorada no Brasil. O presente estudo, ganha relevância, por se propor a produzir conhecimento sobre a paternidade na adolescência, contribuindo à ampliação do marco teórico de referência no Brasil. Para desenvolvimento deste artigo, valeu-se da metodologia descritiva alicerçada em pesquisa bibliográfica, abordando, inicialmente, a questão da adolescência, a sexualidade e a gravidez e em seguida o papel do pai adolescente. A gravidez na adolescência não é uma questão apenas feminina, pois o pai adolescente faz parte deste fato, na sua dimensão bio-psico-social, e deve ter responsabilidades e envolvimento sócio-afetivo desde a concepção do filho. Portanto, para que o adolescente pai possa assumir a paternidade na perspectiva integral e responsável é necessário que ele receba informação, orientação e apoio, tanto da família como do Poder Público, por meio de políticas públicas, como suporte ao exercício da paternidade.

Palavras-chave: gravidez, adolescência, maternidade, paternidade.

\footnotetext{
${ }^{1}$ Doutorando em Psicologia - UCES- Mestre em Educação. Especialista em Teoria Psicanalítica e Psicologia Educacional. Professor Assistente da Universidade Estadual do Sudoeste da Bahia, Jequié, Bahia, Brasil. Email: josmaruesb@hotmail.com.

2 Doutora em Educação. Professora Plena da Universidade Estadual do Sudoeste da Bahia, Área de Ensino, Jequié, Bahia, Brasil. Email: tinaduarte2@gmail.com.
} 


\section{Summary}

Unplanned pregnancy, maternity and parenthood among adolescents are issues that in the last decades have been worrying, experts and stakeholders in the areas of human rights, as well as researchers and academics. This study aimed to contribute to the systematization of scientific and academic knowledge on adolescent fatherhood and the exercise of the paternal function, a theme that is still little explored in Brazil. This study becomes relevant as it proposes to produce knowledge on fatherhood in adolescence, contributing to the expansion of a theoretical framework in Brazil. To develop this article, we used a descriptive methodology grounded in literature review, initially addressing the issue of adolescence, sexuality and pregnancy and then the role of the adolescent father. Teenage pregnancy is not only a women's issue, as the teenage father is part of this happening in its bio-psycho-social dimension, and must have responsibility and socio-affective involvement from the conception of the child. Thus, in order to take paternity in full perspective and responsibility, the teenage father should receive information, guidance and support of both the family and the public administration, through public policies, to support the exercise of parenthood.

Keywords: pregnancy, adolescence, motherhood, fatherhood. 